\title{
Comparison of the rapid plasma reagin card test and other screening tests for treponemal disease in patients attending a venereal disease clinic
}

\author{
G. SCRIMGEOUR AND P. RODIN \\ From the Venereal Diseases Reference Laboratory (P.H.L.S.) and the Whitechapel Clinic, The London Hospital
}

The rapid plasma reagin (RPR) card test for syphilis and other treponematoses (Portnoy, Brewer, and Harris, 1962) was originally developed for use in field work, where equipment such as centrifuges, microscopes, rotating machines, and water baths was not available. It is a flocculation test in which a modified Venereal Disease Research Laboratory (VDRL) antigen containing charcoal particles is used. By the use of machine rotation and other technical changes the test was modified for largescale testing (Portnoy, 1963). A further development is the automated reagin test (ART) described by McGrew, Ducros, Stout, and Falcone (1968), in which RPR card test antigen is used.

Sera submitted to the Venereal Diseases Reference Laboratory from the Whitechapel Clinic are screened by a Reiter protein complement-fixation test (RPCFT) and by an ART in which an RPR card test antigen prepared in the laboratory is used. This routine is based on the results of a previous investigation (Wilkinson, Scrimgeour, and Rodin, 1972) in which this combination of screening tests was found to be the most useful of those tried. It was decided to compare the sensitivity of these routine screening tests with that of the RPR card test.

\section{Material and methods}

The sera studied were 1,999 consecutive samples from patients attending the Whitechapel Clinic over a 10-week period from January to March, 1972. These were tested by the following procedures:

(1) RPCFT

(2) ART using an RPR antigen prepared in the laboratory

(3) RPR card test

A quantitative VDRL slide test and a quantitative RPR card test were performed on 141 sera which were positive in one or more of the screening tests. Sera for the RPCFT and VDRL quantitative test were heated to $56^{\circ} \mathrm{C}$. for $30 \mathrm{~min}$. before testing; sera for the AR and RPR tests

Received for publication September 11, 1972

Addresss for reprints : Dr. G. Scrimgeour, Public Health Laboratories, Havelock Hospital, Hylton Road, Sunderland SR4 8AE were tested unheated. The RPR card test is supplied commercially in a kit consisting of:

Cards marked with ten circular test areas.

Disposable pipettes ('dispenstirs') for delivering 0.05 ml. serum.

RPR antigen (ready for use).

A plastic container and needle for dispensing $1 / 60 \mathrm{ml}$. antigen.

Control cards are available separately. These have three marked circular areas, each of which is impregnated with a dried serum, one being negative, one reactive, and one minimally reactive in the test. The dried sera are reconstituted with $0.05 \mathrm{ml}$. sterile distilled water and the test is carried out in the normal way.

In the performance of the test $1 / 60 \mathrm{ml}$. of antigen is dropped onto $0.05 \mathrm{ml}$. serum which has been spread over a marked area on a test card; the cards with serum and antigen are then rotated at 100 r.p.m. for $8 \mathrm{~min}$. at room temperature before reading. Flocculation can readily be observed without the use of a microscope because of the charcoal in the antigen. Results are given as reactive, minimally reactive, or negative by comparison with the control card. RPR tests were repeated on sera giving minimal reactions.

The RPR card tests were performed by one of us (G.S.) and the RPCF, AR, and VDRL tests by technicians accustomed to their performance; neither knew the results of the other's tests at the time they were done. When considered necessary, confirmatory tests (FTA-ABS and TPI) were carried out; many of the sera found positive by the screening tests were, in fact, from known cases of treponemal disease and had had confirmatory tests in the past. A clinical assessment was made by one of us (P.R.) of those patients showing reactivity in one or more tests and they were classified as follows:

(1) Early syphilis, which included primary syphilis, secondary syphilis, and latent disease in the first year of infection.

(2) Late syphilis, which included late symptomatic syphilis and latent disease after the first year of infection.

(3) Congenital syphilis (late).

(4) Latent treponemal disease (? syphilis ? yaws), where it was not possible to determine whether the positive tests were the result of syphilis or yaws.

(5) Yaws in childhood, where there was a definite history of yaws in early life. 
(6) No treponemal disease, if confirmatory tests were negative and there was no history or clinical evidence of treponemal infection.

Groups 1 to 4 were further subdivided into treated and untreated cases, but this was not done for the 'yaws in childhood' group as the history of treatment in these cases was often unreliable.

\section{Results}

Of the 1,999 sera tested, 157 gave positive results in one or more tests; these were from 145 patients (106 men and 39 women). To avoid loading the results, only the first serum received from patients with more than one positive specimen was included in the analysis. Table I shows the results of screening tests in the 137 patients with treponemal disease. Eight sera gave positive results in one or more tests which were considered to be false reactions on the grounds of negative confirmatory tests and absence of a history or clinical evidence of infection. Of these eight, one was positive in the RPCFT only, four were positive in both AR and RPR card tests and in the VDRL slide test, and three were positive in the RPR card test only. Of those positive in both AR and RPR card tests, two were known chronic false positive reactors.

All but ten patients included as cases of treponemal infection had reactive FTA-ABS tests on the presenting specimen or on a previous one. Of these ten, five who did not have FTA-ABS tests were diagnosed before the end of 1967 and had been confirmed as cases of treponemal disease by a positive TPI test. The other five cases were as follows:

(1) A patient treated for dark-ground positive primary syphilis who did not have an FTA-ABS or TPI test performed until 1972 when they were both negative.
(2) A patient with treated congenital syphilis who did not have a TPI test but whose serum was non-reactive in the FTA-ABS test.

(3) A patient treated for early latent syphilis in 1959 who did not have FTA-ABS or TPI tests.

(4) A patient with reactive RPR and VDRL tests and a non-reactive FTA-ABS test who had a history of yaws infection in childhood.

(5) Another patient with a history of yaws in childhood who had reactive RPCF, AR, and RPR card tests, but who unfortunately did not have confirmatory tests performed.

Both of the patients with a history of yaws (4 and 5) had scars compatible with the diagnosis.

The RPR card test failed to pick up ten patients with treponemal disease found to be positive by the present routine screening combination of RPCFT and ART; of these, five were treated cases of acquired syphilis, two were cases of latent treponemal disease (? yaws? syphilis), and three came into the 'yaws in childhood' category. On the other hand, the present routine screening tests missed twenty cases of treponemal disease positive by the RPR card test; these were twelve treated and three untreated cases of treponemal disease and five with a history of yaws in childhood. Seven of the treated cases and one of the untreated cases were diagnosed as definite syphilis, the others had latent disease which could have been yaws or syphilis.

One RPR card test was repeated because of the findings in other tests. This serum, from a patient with treated primary syphilis, gave a negative qualitative RPR card test but positive RPCF and AR tests; the VDRL slide test titre was 4 . When the RPR card test was performed quantitatively it was found that the serum gave a prozone phenomenon, being negative when tested undiluted, but positive at titres of 2,4 , and 8 ; this was therefore not included

TABLE I Diagnoses in 137 patients with reactive screening tests for syphilis, excluding those with false positive results

\begin{tabular}{|c|c|c|c|c|c|}
\hline Diagnosis & Treated & Total sera reactive & $R P R$ reactive & RPCFT reactive & $A R T$ reactive \\
\hline \multicolumn{6}{|l|}{ Syphilis: } \\
\hline Early & Yes & 17 & $15(3)^{\mathrm{a}}$ & 12 & 11 \\
\hline Late & $\begin{array}{l}\text { No } \\
\text { Yes }\end{array}$ & $\begin{array}{r}5 \\
34\end{array}$ & 5 & 5 & 5 \\
\hline Late & $\begin{array}{l}\text { Yes } \\
\text { No }\end{array}$ & $\begin{array}{r}34 \\
9\end{array}$ & $\begin{array}{r}31 \\
9\end{array}$ & 26 & 30 \\
\hline Congenital & Yes & 7 & $\begin{array}{l}9(1) \\
7\end{array}$ & $\begin{array}{l}0 \\
1\end{array}$ & 6 \\
\hline $\begin{array}{l}\text { Latent treponemal disease } \\
\text { (? syphilis ? yaws) }\end{array}$ & $\begin{array}{l}\text { Yes } \\
\text { No }\end{array}$ & $\begin{array}{l}29 \\
13\end{array}$ & $\begin{array}{l}29(3) \\
11(4)\end{array}$ & $\begin{array}{l}15 \\
10\end{array}$ & $\begin{array}{r}21 \\
8\end{array}$ \\
\hline History of yaws in childhood & ?b & 23 & $20(5)$ & 15 & 12 \\
\hline Total & & 137 & $127(16)$ & 90 & 100 \\
\hline
\end{tabular}

aFigures in brackets indicate the number of sera minimally reactive in the RPR card test

bThe history of treatment was unreliable in this group 
in Table I (in which results of qualitative screening tests are given) as a positive RPR card test result.

\section{Discussion}

The RPR card test was found to be easy to perform, although some difficulty was at first experienced in reading minimal reactions. This test using a commercial antigen was found to be more sensitive than an AR test using the same antigen prepared in the laboratory. Thus, 29 sera from patients with treponemal disease were reactive in the RPR card test and negative in the AR test, but only two sera which were non-reactive in the RPR card test were reactive in the AR test; one of these two was the specimen which gave a prozone phenomenon in the RPR card test. Of the 29 reactive in the RPR card test but nonreactive in the AR test, thirteen gave minimal reactions in the RPR card test; AR test results are read as either reactive or non-reactive, with no weakly or minimally reactive category. The antigen used in the AR test in this study was comparable in sensitivity to the commercial product generally available in Great Britain, but may be a little less sensitive than a reagent obtainable in the U.S.A. McGrew and others (1968) found the RPR and AR tests comparable in sensitivity. Despite its sensitivity the RPR card test produced only seven false positive results in the present study, an incidence of less than four per thousand sera tested. Walker (1971) found a considerably higher incidence of false positive results, which occurred mainly in specimens from antenatal clinics.

The RPCFT was positive in ten cases of treponemal disease in which the RPR card test was negative, but was negative in 47 cases in which the RPR card test was positive. A combination of the RPCFT and RPR card test picked up all 137 cases of treponemal disease in this study which gave positive results in the screening tests. It was not practicable in a series of this size to determine the total number of patients who had a history of treponemal disease but whose sera had become negative in the screening tests. On the basis of the previous study from this laboratory (Wilkinson and others, 1972), one can say that the RPCFT/ART combination picks up about 58 per cent. of new patients attending the Whitechapel Clinic whose sera are reactive in the FTA-ABS test. The addition of the RPR card test in this study resulted in the finding of twenty cases which were not positive in the routine screen, so it might be considered that the inclusion of the RPR card test would improve the pick-up rate slightly. It must be pointed out, however, that the two studies were not strictly comparable, as the earlier one included only patients attending for the first time or re-attending with a condition other than the disease for which they had originally been treated. The present series included all patients from whom serum was submitted over a 10-week period and therefore included some patients attending for follow-up after treatment for treponemal disease. This may account for the fact that overall the ART appeared to be more sensitive than the RPCFT in this study, but in untreated cases the RPCFT was as sensitive as the ART. The RPCFT is known to be less sensitive than reagin tests in treated cases of late congenital syphilis (Förström, 1967) and this was noted in the present study.

Only one serum gave a prozone phenomenon in the RPR card test; this was apparently more common before the procedure of the test was modified to avoid premixing of the serum and antigen before rotation (Portnoy, 1965). The comparison of the quantitative RPR card and VDRL slide tests (Table II) showed that the former was more sensitive with the majority of sera.This finding was similar to that of Falcone, Stout, and Moore (1964). In the present study difficulty was sometimes found in reading the end-point in the RPR card test titration, as there was only a gradual change in the appearance of the flocculation through the dilutions.

TABLE II $A$ comparison of RPR card test and VDRL slide test titres in 141 sera from 129 patients with treponemal disease

\begin{tabular}{|c|c|c|c|c|c|c|c|c|c|c|}
\hline \multirow{2}{*}{$\begin{array}{l}R P R \\
\text { titre }\end{array}$} & \multirow{2}{*}{$\begin{array}{l}\text { No. of } \\
\text { sera }\end{array}$} & \multicolumn{9}{|c|}{$V D R L$ titre } \\
\hline & & Neg. & $W R$ & 1 & 2 & 4 & 8 & 16 & 32 & 64 \\
\hline $\begin{array}{l}\text { Neg. } \\
\text { Rm } \\
1 \\
2 \\
4 \\
8 \\
16 \\
32 \\
64 \\
128\end{array}$ & $\begin{array}{r}8 \\
17 \\
20 \\
41 \\
19 \\
18 \\
8 \\
4 \\
4 \\
2\end{array}$ & $\begin{array}{l}5 \\
8 \\
7 \\
4\end{array}$ & $\begin{array}{r}3 \\
8 \\
11 \\
20 \\
7 \\
1\end{array}$ & $\begin{array}{r}2 \\
13 \\
5 \\
2\end{array}$ & $\begin{array}{l}1 \\
3 \\
4 \\
8 \\
3\end{array}$ & $\begin{array}{l}1 \\
3 \\
5 \\
1\end{array}$ & $\begin{array}{l}2 \\
3\end{array}$ & $\begin{array}{l}1 \\
1 \\
1 \\
1\end{array}$ & $\begin{array}{l}3 \\
3\end{array}$ & 1 \\
\hline Total & 141 & 24 & 50 & 22 & 19 & 10 & 5 & 4 & 6 & 1 \\
\hline
\end{tabular}

WR = weakly reactive with neat serum

$\mathbf{R m}=$ minimallv reactive with neat serum

The other factor which might be considered in comparing the RPR card test and the AR test is the rate at which a technician can perform the tests. The present AR test machine can perform 100 tests per hour, but Walker (1971) claimed a rate of 100 tests in $29 \mathrm{~min}$. for the RPR card test. However, the AR test machine should not require the constant attendance of the technician. Certainly the RPR 
card test is very useful when only a few tests have to be performed at a time, especially as the antigen remains stable for some months at $4^{\circ} \mathrm{C}$.

\section{Summary}

A total of 1,999 consecutive samples of serum trom patients attending the Whitechapel Clinic was screened by the following tests: Reiter protein complement-fixation test, automated reagin test using a rapid plasma reagin card test antigen prepared in the laboratory, and rapid plasma reagin card test. Positive results in one or more of the screening tests were given by 157 sera from 145 patients. A clinical assessment was made of the seropositive patients and they were classified according to the nature and stage of their treponemal infection. Eight of the sera were considered to give false positive results.

The RPR card test was found to be the most sensitive of the three screening tests used; it was positive in 127 patients with treponemal disease compared with ninety positive results with the RPCFT and one hundred with the ART.

We should like to thank Hynson, Wescott, and Dunning, Inc. (Baltimore, Maryland) and Becton Dickinson \& Co. (Wembley, Middlesex) for the supply of RPR card test kits, Dr. A. E. Wilkinson, Director of the Venereal Diseases Reference Laboratory, for his guidance, and the technical staff who performed the RPCFT, ART, and VDRL tests.

\section{References}

Falcone, V. H., Stout, G. W., and Moore, M. B., JR. (1964) Publ. Hlth Rep. (Wash.), 79, 491

FörströM, L. (1967) Acta derm.-venereol. (Stockh.), 47, Suppl. 59

McGrew, B. E., DuCros, M. J. F., Stout, G. W., and Falcone, V. H. (1968) Amer. F. clin. Path., 50, 52

PorTNOy, J. (1963) Ibid., 40, 473

- (1965) Publ. Hlth Lab., 23, 43
- - Brewer, J. H., and Harris, A. (1962) Publ. Hlth Rep. (Wash.), 77, 645

WALKER, A. N. (1971) Brit. F. vener. Dis., 47, 259

WILKINSON, A. E., ScRIMGEOUR, G., and RodIN, P. (1972) f. clin. Path., 25, 437

Addendum After the completion of the study the question arose of a possible effect on the sensitivity of the AR test resulting from the use of an antigen prepared in the laboratory rather than a commercial antigen. The results of tests using both types of antigen, which were done in parallel on 293 sera, suggest that this was not the case. Eighteen sera gave reactive results, seventeen with both antigens and the remaining one only with the antigen prepared in the laboratory. The commercial antigen was supplied by Hynson, Westcott, and Dunning Inc., Baltimore, Maryland.

Comparaison de l'épreuve rapide réaginique sur carte avec le plasma (RPR) et des autres épreuves de détection systématique pour la maladie tréponémique chez les consultants d'une clinique vénéréologique

\section{SOMMAIRE}

Un total de 1,999 échantillons consécutifs de sérums, provenant de consultants de la Whitechapel Clinic, fut soumis aux tests suivants: test de fixation du complément à la protéine de Reiter, test de réagine par dispositif automatique utilisant un antigène pour épreuve rapide réaginique avec le plasma sur carte préparé au laboratoire, test rapide réaginique avec plasma sur carte. On trouva 157 résultats positifs pour 145 malades à un ou plusieurs tests de détection. Les malades séro-positifs furent répartis cliniquement et classés en fonction de la nature et du stade de leur infection tréponémique. Huit de ces sérums furent considérés comme donnant des résultats faussement positifs.

L'épreuve RPR sur carte s'est montrée la plus sensible des trois tests de sélection utilisés; elle a été positive chez 127 malades atteints de tréponématose contre 90 résultats positifs avec la réaction de déviation de fixation du complément à l'antigène de Reiter et 100 avec le test automatisé. 